\title{
A Study on Dosa Making Machine and Dosa Making Process
}

\author{
Dr.T. Vigraman ${ }^{* 1}$, N.Venkata Mukesh ${ }^{2}$, J. Surya Prasad $^{3}$ and K. Chandrashekar $^{4}$ \\ ${ }^{1}$ Professor, ${ }^{2,3,4}$ Final year students, Department of Mechanical Engineering, Sasi Institute of \\ Technology \& Engineering, Tadepalligudem, Andhra Pradesh, India. 1tvr@sasi.ac.in
}

\begin{abstract}
The objective of the study was to design and fabricate a automatic dosa making machine for commercial purpose. Dosa is an unavoidable food item in most of the Indian homes. In this machine use of complex Programmable Logic Controller (PLC) circuits for various operations like pouring, scraping and spreading the flour is eliminated. With the addition of soya bean batter along with the rice and black gram batter, the calories of dosa and quality of dosa is enhanced. The addition of soya bean increases protein content and reduces carbohydrate in the dosa. Further, the change in composition of dosa flour and thickness variation in the dosa, requires considerable change in design parameters such as material selection, speed of rotation, heat input and viscosity of the batter spread on the pan. This equipment is capable of making a single large dosa which can be cut into small dosas.
\end{abstract}

Keywords: Dosa, batter, pan, machine, assembly and solidworks.

\section{INTRODUCTION}

Shaji et al discussed the origin of dosa in India and types of dosas such as thick soft dosa with varities of toppings consumed in Tamilnadu, thin crisp dosa sold in Karnataka and dosa's served in Udipi restaurents of Kerala. Meganathan et al conducted research among rural folks from Kerala to know about the difficulties while making dosas at home. The objective of his study is to understand the process of making different types of dosas and evolve appropriate engineering mechanisms for making dosas coomercially. Praise Sabu et al developed an automatic dosa making machine so that this food can be manufactured commercially within short time and served to people in the morning for breakfast. Chandhrasekar et al developed a fully automated dosa, which is capable of making dosas with the press of a button. Rakshitha et al designed and developed a machine capable of making three different types of dosas to serve during breakfast and dinner time. Kumbahar and Admuthe discussed about use of control systems such as numerical control, programmable logic control, and other industrial control systems in automatic machines. Further, the authors probed the applications of information technology, computer-aided design and manufacturing, controls in industrial machinery and processes for reducing the need for human intervention.

Tiwari et al studied the change in batter volume of gram powder mixed with water in varying proportions and these samples were fermented at various temperature 40, 50, 60, 70 and $90{ }^{\circ} \mathrm{C}$ and it was found that the unfermented batter volume was $1120 \mathrm{ml}$ and $825 \mathrm{ml}$ at 40 and $90{ }^{\circ} \mathrm{C}$, respectively; after fermentation period of $24 \mathrm{~h}$, the increase in the batter volume was found to decrease from $69.84 \%$ to $26.66 \%$. The reason for unfermented batter and fermented batter volume decrease was attributed to rise in drying temperature. Further, the decrease in batter volume and fermentation level at elevated temperature may be due to inactivation of enzymes at higher temperatures. Dosa is made with a mixture of ground and fermented flour made with rice and black gram flour, which is suspended in water as a colloidal substance. In the present study, the composition of the mixture is varied with the addition of soya bean flour along with the rice and black gram dhal flour. This change in the composition alters the calories of dosa and enhances quality of food. The addition of soya bean increases protein content and reduces carbohydrate in the dosa. Further, the change in composition of dosa flour and thickness variation in the dosa, requires consideration of various design parameters such as material selection, speed of operation, heat input and viscosity of the flour spread on the pan. Considering these factors, this equipment is designed and fabricated.

\section{METHODOLOGY}

\subsection{DESIGN OF EQUIPMENT}

This equipment consists of several subsystems and components. A frame to support the motor, shaft, gas burner and holding fixtures, a pan which is a circular disc, flour feeding mechanism and a hopper are modelled and shown in Fig. 1. The frame is made with steel pipes and angles. A cam mechanism is provided to permit flow of metered quantity of flour on the pan for a specified period of time. Thus the flow of batter is controlled, metered and allowed to flow at six places, so that six dosas can be cooked within three minute. 

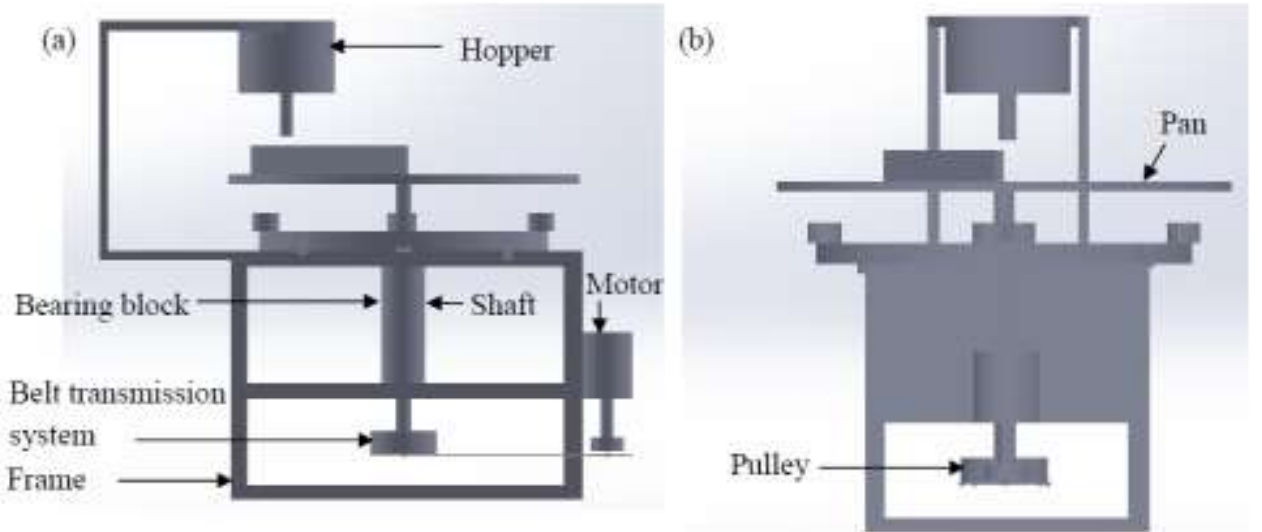

Fig. 1 a) The front view of the machine model, b) the side view of the machine.

The motor and belt transmission system is created using solid work software. Individual part drawings are created and assembled to make the sub assembly using the assembly options in the software. After making these subassemblies, a three dimensional assembled machine is created which is shown in Fig.2. In the diagram a shaft is shown which is connected to a pulley to provide power to the large circular disc made with AISI 304 stainless steel. AISI 304 stainless steel possesses good high temperature and corrosion resistant properties.

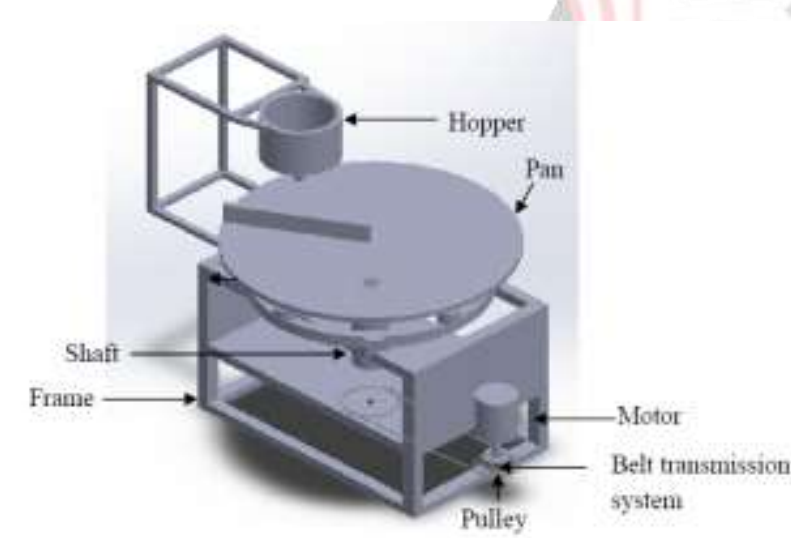

Fig. 2 The three dimensional model of the dosa making machine.

This sub assembly model of the shaft and bearing blocks are created and assembled with the belt transmission system. Two bearing blocks with two ball bearings at the ends of the shaft are used in this system to support the shaft. These bearing blocks are fixed with the steel frame. The solidwork model is created with the above mentioned parts and assembled with the disc (a rotating member). At the bottom of the disc three burners are provided to heat the disc uniformly to cook the dosa. The gas burner models are created and assembled at the bottom surface of the pan. The photograph shown in Fig. 3 reveals the burner assembled at the bottom of the pan.

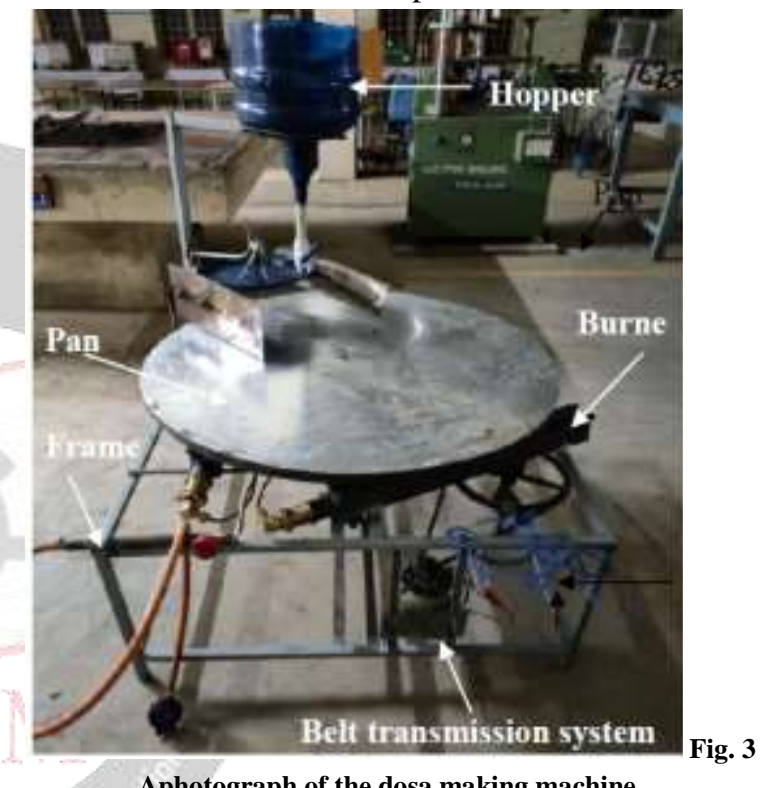

Aphotograph of the dosa making machine.

\section{RESULTS AND DISCUSSIONS}

The performance of the dosa machine was tested and the following parameters were estimated. The calculated power required for rotating the pan is adequate. The speed of the rotating pan is fixed which is a limiting factor. Therefore, the number of dosas produced per hour cannot be varied. The calculated time for roasting a dosa is approximately $20 \mathrm{~s}$, on the other hand the time taken for one complete revolution of the disc is $19.56 \mathrm{~s}$. Therefore, a timer is provided to control the scrubber and batter feeding mechanism to vary the cooking time.

Table 1 The dosa making machine operating parameters.

\begin{tabular}{|c|c|c|c|c|c|}
\hline Power kW & $\begin{array}{c}\text { Calculated speed in } \\
\mathrm{rpm}\end{array}$ & $\begin{array}{c}\text { Actual speed obtained in } \\
\mathrm{rpm}\end{array}$ & Torque N.m & $\begin{array}{c}\text { Time required for roasting } \\
\text { in s }\end{array}$ & $\begin{array}{c}\text { Time taken for one revolution in } \\
\mathrm{s}\end{array}$ \\
\hline 0.37 & 6.2 & 4.2 & 570 & 20 \\
\hline
\end{tabular}


This equipment consumes less power and it can be maintained easily In the present study, the composition of the mixture is varied with the addition of soya bean flour along with the rice and black gram dhal flour. This change in the composition alters the calories of dosa and enhances quality of food. The addition of soya bean increases protein content and reduces carbohydrate in the dosa. Further, the change in composition of dosa flour and thickness variation in the dosa, requires consideration of various design parameters such as material selection, speed of operation, heat input and viscosity of the flour spread on the pan. Therefore, a timer is provided to control the scrubber and batter feeding mechanism to vary the cooking time. Considering these factors, this equipment is designed and fabricated. Furthermore, this machine is capable of making at least six small dosas at a time. This machine is capable of making thin and thick dosas with and without topping on the dosa's with several ingredients. product quality, Journal of Food Engineering, Volume 78, Issue 1, January 2007, pp 356-360.

\section{CONCLUSIONS}

The Dosa Making Machine is working satisfactorily. The cost of the machine is less and can be used for commercial purpose. This equipment consumes less power and it can be maintained easily In the present study, the composition of the mixture is varied with the addition of soya bean flour along with the rice and black gram dhal flour. This change in the composition alters the calories of dosa and enhances quality of food. The addition of soya bean increases protein content and reduces carbohydrate in the dosa. Further, this machine is capable of making at least six small dosas at a time. Further, this machine is capable of making thin and thick dosas with and without topping the dosa's with several ingredients.

\section{REFERENCES}

[1] Meganathan D, Automatic Dosa Making Machine, April 2018, International Journal of Research Culture Society, (IJRCS), 2(4), pp 97-103.

[2] Rakshitha M, Design and Development Automated Food Maker, June 2019, International Research ournal of Engineering and Technology (IRJET), 6 (6), pp 599-604.

[3] Praise Sabu, Design and Development of Automated Appam Maker, April 2017, International Journal for Innovative Research in Science \& Technology (IJIRST), 3 (11), pp 313-321.

[4] Chandra Sekhar K, Automataed Portable Dosa Making Machine, BMS Institute of Technology \& Management. Bangalore, Project report.

[5] Shaji K.S, Design and Development of an Automatic Dosa Maker for Indian Households, M. S. Ramaiah University of Applied Sciences, Bangalore.

[6] Tiwari B.K, Jagan Mohan R and Vasan B.S, Effect of heat processing on milling of black gram and its end 